\title{
Remittances and Household Welfare in Nigeria
}

\author{
Olayinka Akanle ${ }^{1}$ and Jimi O. Adesina ${ }^{2}$ \\ ${ }^{1}$ Department of Sociology, University of Ibadan, Nigeria/ \\ College of Graduate Studies, University of South Africa (UNISA), South Africa. \\ yakanle@yahoo.com, yk.akanle@ui.edu.ng, akanlo@unisa.ac.za \\ ${ }^{2}$ College of Graduate Studies, University of South Africa (UNISA), South Africa
}

\begin{abstract}
Remittances remain among the most researched issues in contemporary international migrations, poverty alleviation, welfare dynamics and development financing in developing countries. This is particularly so as remittances continue to rival Official Development Assistance (ODA) and Foreign Direct Investment (FDI) and it is being argued to be more effective in driving development than aid. While studies exist on influences of remittances on household welfare in developing countries, many more are needed to sufficiently understand the actual roles of remittances in households' welfare in Sub-Saharan Africa- one of the poorest regions in the world. The relationship between remittances and household welfare has particularly not been sufficiently empirically tested in Nigeria- the most populous nation in Africa, among the poorest countries in the world and the highest remittances receiving nation in Africa. This article therefore examined the influence of remittances on households' welfare in Nigeria. This is a very important article considering the increasing trend of migration and efforts to reduce poverty and inequality. Secondary and primary data were gathered for this article. Secondary data were gathered through documents, journal articles and newspapers, among others, while primary data were gathered through quantitative and qualitative methods between 2015 and 2016. Appreciable positive relationships were found between remittances and household welfare. Unlike many previous studies which claimed remittances receiving households mostly spend remittances on consumptions, more robust expenditure patterns were found. Expression of welfare was also found to be beyond the commonly noted to include important intangible welfare credits like community respect for remittances receiving households. It is concuded that development experts, partners, governments, groups and individuals should therefore better appreciate and appropriate both the financial and non-material effects of remittances on inequality and poverty in developing countries especially of Africa.
\end{abstract}

Key Words: Remittances, Household Welfare, Lagos, Nigeria.

\section{Introduction}

This article examined the important and useful microlevel factors and forces that can help understand household welfare trajectories ${ }^{\mathrm{ii}}$ of remittances in Africa through the case of Nigeria. Many existing works have focused largely on macro level politicoeconomic narratives and repertoires of welfare, poverty and remittances in Africa without sufficient attention to important micro-level household data and findings that moderate remittances outcomes (see also Fonta et al, 20I5, von Burgsdorff, 20I2, Lu, 2012, Kiiru, 2010, Balde, 2009, Devarajan, 2008, Uduku, 2002). While there has been increase in knowledge on remittances and influences on poverty in developing countries as remittances continue to soar in these countries (Dieye, 20I5), more researches are certainly needed at households' level to significantly understand the actual influence of migrants' remittances on welfare. This is particularly important as overall poverty and reversed welfare hold sway, and increasing, in many African countries even as remittances continue to grow in the region for example.

Migrant households at origin are particularly important points of research on remittances and welfare for three major reasons. First, they are the direct and ultimate beneficiaries of remittances. Second, they are most likely to have the full knowledge of remittances welfare existential intersectionalities in the households. Third, the stories migrants' households telliii about migration, remittances and welfare can lead to the right knowledge of Migration and Development especially in Africa (Akanle and Adesina, 2017). In the face of ascendancy of international migration and substantial volume of remittances from the migrants to their left- 
behind households in developing countries, these tripartite reasons for household-based researches are critical if remittances will ever sustainably drive wellbeing and alleviate poverty in developing countries in the long run (see also Akanle and Adesina, 2017, The World Bank, 2015, Gabriel, 20I5, Dzingirai, Mutopo and Landau, 2014, Olowa and Awoyemi, 2014, Olowa et al, 2013).

There is in fact substantial amount of literature on the influence of remittances on households welfare and the dominant consensus is that positive relationships exist between them (Anderson, 2014, Abbas et al, 2014, Arifeen, 2013, Chukwuone et al, 2012, Anyanwu, 20II, Nwajiuba, 2005). More researches are however needed to sufficiently understand the full ramifications and interlinkages of remittances and household welfare. While common narratives of remittances are on the positive influences on households' welfare (the so-called Migration Optimists) (Fonta, et al, 2015, Olowa and Awoyemi, 20l4, Olowa et al, 20I3, Chukwuone et al, 20I2, de Haas, 2007), a lot is yet to be known about the micro-level household dynamics that will over time determine the real sustainable influences of remittances on left-behind ${ }^{\text {iv }}$ households. This is why the on-going theoretical debates between the Migration Optimists and Migration Pessimists continue to be acrimonious, intense and inconclusive (Fonta et al, 2015: 346) as the actual short and long run influences of remittances on welfare remain insufficiently understood especially in Africa and, particularly, Nigeria (see also Odozi, Awoyemi and Omonona, 2010 for empirical contributions to these debates from Nigeria). Although few studies exist on Sub-Saharan Africa that can assist in understanding Nigeria's case somewhat broadly (Fonta et al, 2015, Gabriel, 2015, Olowa and Awoyemi, 2014, Olowa et al, 20I3, Chukwuone et al, 20I2); particular scholarly works such as this current one are significantly more useful. This article therefore contributes to literature and data on international migrants' remittances and their origin households' welfare. To do this, secondary and primary data were gathered and analysed on elements (nature, volume and frequency') and influences of remittances on households left-behind in Nigeria by migrants.

According to the The World Bank (2015), remittances to Sub-Saharan African region is projected to amount to $\$ 33$ billion US dollars and Nigeria alone accounts for about two-thirds of the total remittances into the region at around $\$ 21$ billion US dollars. In 2014, there was a sustained strong growth in remittances into the region of Sub-Sahara Africa as witnessed in particular cases of, for example, Kenya (I0.7 percent), South Africa (7.I percent) and Uganda (6.8 percent) (see Dieye, 2015). 3195
The overall remittances outlook is projected to be $\$ 34$ billion US dollars in 2016 and $\$ 36$ billion dollars in 2017 (The World Bank, 2015). Remittances are considered so critical to some countries in the region that Liberia, Lesotho and Gambia, for instance, may find survival difficult without them as remittances account for about 20 per cent of their GDP (Gabriel, 2015). Even while it is projected that the flow of remittances may slow down due to global economic recession and as many countries of destination tighten immigration procedures, remittances to SubSaharan Africa regardless remain massive and noteworthy.

Against the background of continuous debate around effectiveness of remittances on welfare and poverty reduction in migrant households, it is imperative to contribute to data and literature on the problematic by not only limiting research attention to remittances receiving households but also nonremittances-receiving households. This will enable a robust capturing of remittances' implications for household welfare. The non-remittances' receiving households thus become critical counterfactual elements in understanding influences of remittances on welfare and that is what this article has done methodologically through its research engagements. This article has two major research questions. First, what are the elements (nature, volume, and frequency) of remittance flows to receiving households in manners that they are indicative of influences? Second, what is the influence of international remittances on the welfare of receiving households? These research questions guided the research process and they led to important contributions to literature and knowledge on the subject.

\section{Literature Review: Poverty/Welfare in Africa- The Why of Remittances}

In this section we surveyed the literature landscape paying close attention to poverty as the major driver of intellectual and policy interests in remittances in developing countries and Sub-Saharan Africa. Most literatures on remittances to sub-Saharan Africa are premised on poverty and inequality components as interfaces of impacts (Fonta et al, 2015, Odozi, Awoyemi and Omonona, 2010 and Akanle and Olutayo, 2009). Literatures converge that significant proportions of migrations from Sub-Saharan Africa to the North and some parts of the South are economic and driven by poverty and this accounts for why most remittances into the sub-continent are targeted towards poverty alleviation and household welfare improvements thereby accounting for continuous scholarly and practice interests (Akanle and Adesina, 2017, Akanle, Alemu and Adesina, 2016, Dieye, 2015, 
The World Bank, 20I5, Gabriel, 2015). Poverty, as demonstrative face of reversed welfare, is one of the most daunting problems confronting Africa (Chandy, Ledlie, and Penciakova, 2013, Akanle, 2013, Akanle and Olutayo, 20II, Adesina, 2002/2006). Concerned with the widespread poverty in Africa and other developing countries, The World Bank Annual Report (2013) centered on strategising for a world free of poverty and more inclusive sharing of prosperity. In related version, The World Development Report (2013) was on Jobs issues ultimately concerned with ending unemployment and poverty largely in poor developing countries.

Poverty is pronounced deprivation in well-being, negation of welfare, material deprivation, low level of achievement in education and health, nonachievement or lack of ability to demand rights...vulnerability, exposure to risk...beggary, penury, financial embarrassment, a sense of inferiority... (Alkire, et al, 20I5, Akanle, 20I3, World Bank, 20I3, Alkire and Santos, 20I0). A common ground is that poverty is undesirable and it is to be reduced and eradicated. This is why governments, people, development partners and so on attempt to evolve policies, strategies and instruments to end it. These policies and instruments however need more researches to be more effective. For instance, for about half a century, governments across the world including those on the continent of Africa have introduced varying policies to address poverty in the developing countries especially in Africa, Asia and Latin America yet the problem persists. While antipoverty policies have had different outcomes across continents, the experiences in Sub-Saharan African nations are somewhat identical even within international migration frameworks (Akanle and Olutayo, 20I I, Togunde and Osagie, 2009, de Haas, 2007).

Most of the policies on poverty in Sub-Saharan Africa did not have the intended outcomes and they largely faired below average. Emphasizing this, the 2014 African Millennium Development Goals (MDG) Report concluded that most African countries have failed to appreciably improve wellbeing, have not substantially reduce poverty and inequality and this is despite increased growth rate over the last 10 years (The MDG Report, 20/4). Reduction in poverty rate is nearly negligible over the last 10 years in Africa falling from 56.5 percent in 1990 to merely 48.5 percent in 2010 by percentage of people living below $\$ 1.25$ a day benchmark (see 2014 African MDG Report). This disjuncture among policy interventions, increase in number of people in poverty and decline in welfare thus necessitates increasing researches. A major reason poverty remains a growing concern in Africa is that rather than reducing, it either remains http://aps.journals.ac.za constant or is increasing in many circumstances (Akanle, 2013, Anyanwu, 2012, Anyanwu, 20II), except in very few instances like in the cases of Botswana and Mauritius.

Poverty in Africa Sub-Saharan particularly ranged from 50 to 70 percent (The MDG Report, 2014). Related policies in Africa have been very dynamic but the end products have not positively driven sustainable poverty reduction leaving African poverty and reversed welfare burdens comparatively heavy (The World Bank, 2013, Akanle, 2013, Akanle and Olutayo, 20I I). From Nigeria, Angola, Ghana, Benin, Congo Democratic and Kinshasa, Guinea, Sierra Leone, Ivory Coast, Lesotho, Kenya, Senegal and so on in Africa, below average welfare is pervasive. Many reasons have been given for continued reversed welfare, poverty and jaundiced development in Africa. They include; corruption ${ }^{\mathrm{vi}}$, conflicts and wars, poor infrastructure, political instability, governance failure, dependence on primary products like oil, excessive importations, human rights abuses and policies inconsistencies among others (see Akanle and Adesina, 2015, Dieye, 20I5). It is against these backdrops that remittances from international migrants are becoming globally recognised development lifelines of many developing countries especially in Africa (von Burgsdorff, 20I2).

There are advantages of remittances in improving welfare and reducing poverty in Africa especially over Official Development Assistance (ODA), Foreign Aid and other poverty alleviation and welfare boosting mechanisms. While other instruments like aid and ODAs are subject of intense corruption with as much as 90 per cent of them mismanaged by the political class and government officials (Bodomo, 20I4), remittances go directly to targets- households and beneficiaries- thereby making them less amenable to corruption and mismanagement (Bodomo, 20I4). Remittances also do not suffer from excessive politicisation and political economy of other supports structures in attempts to improve welfare and end poverty. In fact, improving welfare and ending poverty especially in Africa has nearly become a big industry, gargantuan pot of corruption and mismanagement by key actors. Remittances largely do not suffer from these corruption and mismanagement. Hence, remittances do not suffer from strangulating conditionalities, financial interests and political interests of often competing international actors.

Unlike in cases of ODA and aid-tying where gains are sometimes expropriated ${ }^{\text {vii }}$, remittances stay in the receiving households and receiving countries thereby having positive multiplier effects when they are put into positive purposes like starting new businesses, building new houses and beginning commercial 
transportations (Fonta, et al, 2015, Dieye, 2015, Badomo, 2014, Nwaru, lheke, and Onyeweaku, 20II) and so on. Even when remittances are used for consumptions, they may still have direct and indirect, tangible and intangible positive results on welfare (Fonta, et al, 20I5, Badomo, 20I4). These also make it more possible to track and measure the influences of remittances on people's welfare than ODA, aid and other public sources of development finance. Hence, even though international financial flows- like Foreign Direct Investment, ODA and other public financing systems- into Africa and other developing countries are still important, remittances continue to grow substantially while other international financial flows are stagnating and reducing in many circumstances. Even though migrant remittances fall generally in the domain of private resources allocations, this article deals with remittances as development instruments in the context of household welfare mix. This is within the intersectionalities of remittances as household welfare mechanisms in Africa.

\section{Data and Methods}

The objectives of this article are; to examine the nature, volume and frequency (elements) of international migrants' remittances to households and influences of the remittances on households' welfare in Nigeria. This article is part of a larger study undertaken under the South African Research Chair Initiative (SARChl) in Social Policy at the University of South Africa (UNISA) in 2015/2016. Research development and executions lasted one year across Nigeria and South Africa, but the fieldwork/data collection lasted four months in Nigeria (November $I^{\text {st }}$ 2015-February $29^{\text {th }} 2016$ ). The research design was non-experimental. The study prioritised local and micro level data collection at household level to enable in-depth examinations of relevant issues. A combination of quantitative and qualitative techniques was adopted in the study. Unlike many previous studies that concentrated on only quantitative approach (see Fonta et al, 2015, Mishi and Mudziwapasi, 2014, Lu, 2012, Nwaru, Iheke and Onyenweaku, 20II, Kiiru, 2010 and Quartey, 2006 for instance), the triangulated approach (quantitative and qualitative data) adopted in the research provided opportunity for exploring underlying issues in greater detail. While qualitative method allowed deep insight into norms, values, beliefs, attitudes, social relations and influential sociocultural ethos that could be probed in as much depth as possible, the quantitative technique allowed examination of critical mass of issues for description and inferences (see Akanle and Olutayo, 2012, Togunde and Osagie, 2009).
The primary research setting was Lagos, Nigeria. Lagos is a city state and it is the most urbanized part of Nigeria. It is also one of the only three mega cities in Africa. Lagos is the most economically vibrant and buoyant state in the country due to its sociopolitical history, demographic compositions and unique geographic positioning. Lagos has its share of high rate of unemployment, urban poverty, social inequality, relatively youthful, ambitious and educated population and other community characteristics that drive migration and need for kin supports (Akanle, 2012). Although, the individuality that is often characteristic of cities and urban settings may pose a challenge to kinship in Lagos, elements and drivers of primordial filiations are nevertheless present. The unique socio-economic patterns of Lagos could motivate people to seek kinship lifelines- in forms of remittances for instance- as they confront survival challenges in the urban space (Dzingirai, Mutopo, and Landau, 20I4). Importantly also, while Nigeria is the biggest recipient of remittances in Sub-Saharan Africa, Lagos is the main destination of remittances into the country with the receipt of about 60 percent of the remittance inflows, followed by Abuja (Federal Capital Territory [FCT]) with only 15 percent (Akanle, 20II, Hernandez Coss and Bun, 2006). Hence, international migrants tend to characteristically return and settle in urban areas and Lagos is usually the first choice for most of them in Nigeria, due to comparative economic 'boom' (Uduku, 2002:306) and comparatively better infrastructure.

Two main categories of respondents were adopted for the study. The first category was remittances-receiving households and the second category was non-remittances-receiving households to enable counter posing to ascertain how different categories of households fair relative to remittances and welfare. A combination of multi-stage and cluster sampling approach was adopted in selecting areas, households and respondents through senatorial districts, local governments, EAs and Communities/localities based on available secondary information about the research setting. 50 percent (I0) of the 20 LGAs in Lagos were selected and 2 EAs were selected per LGA. Primary and secondary data was collected. Primary data was collected using in-depth (I) (2) interviews (I8 IDIs), Life Histories (8 LHs), 6 Focus Group Discussions (6 FGDs). Participants for these qualitative sessions were selected through purposive sampling. Also, I,II5 questionnaires were administered on households' members selected through systematic sampling. The sampling selections for the quantitative and qualitative components were independent. In other words, people selected for the quantitative were 
totally different from those selected for the qualitative. As can be seen in table $I$ in discussion section below, the characteristics (end of 2)

(3) presented are for members of households facilitated on behalf of the selected households. Hence, the I, II 5 household members selected were either household heads or other designated household members who have sufficient relevant knowledge to speak for the households on the research issues (end of 3).

(4) There were instances where household heads could not give sufficient and elaborate information on the research issues. In such cases, other household members with the best exhaustive relevant knowledge were facilitated.

The primary data was complemented with secondary data from official but unclassified documents from government sources and from development partners/agencies, scholarly/peer reviewed journals, newspaper clippings and reliable official internet sites. Quantitative and qualitative data analyses techniques were used to accommodate all aspects of data gathered. The quantitative data was analysed with the aid of relevant statistical package/software. Quantitative data analysis adopted descriptive and inferential statistics. Multivariate regression analysis was done for exhaustive data analysis. As can be seen from table 6, for example, variables used in the regression were to capture household experiences but through individual key household actors' level. This approach was adopted as proxy household real welfare experiences capturing at household level. This approach was very successful at capturing our objectives because we were able to establish from the onset that the facilitated key actor was household nominee with sufficient and attested remittances and nonremittances households' interactions experience. Qualitative data was also analysed adopting the right analytical tool. Detailed attention was paid to important ethical issues throughout the study. Participants' right of withdrawal was emphasized and guaranteed, informed consents were sought and anonymity, rights and integrity of respondents/participants were respected/protected. The study also eliminated harm and risks to the participants (end of 4).

\section{Data Presentation and Findings}

Table I: Summary Socio-Demographic Characteristics of Households

\begin{tabular}{|c|c|c|c|c|c|c|}
\hline \multirow[b]{2}{*}{ Variables } & \multicolumn{2}{|c|}{$\begin{array}{l}\text { Sample } \\
1 \mid 15)\end{array} \quad(n=$} & \multicolumn{2}{|c|}{$\begin{array}{l}\text { Remittances Receiving } \\
\text { Households (RRHs) } \\
(\mathrm{n}=5 \mathrm{I} I[45.8 \%])\end{array}$} & \multicolumn{2}{|c|}{$\begin{array}{l}\text { Non-Remittances Receiving } \\
\text { Households (NRRHs) } \\
(\mathrm{n}=604[54.2 \%])\end{array}$} \\
\hline & Mean $^{\text {viii }}$ & Std dev & Mean & Std dev & Mean & Std dev \\
\hline Age & 36.55 & 10.83 & 37.74 & 12.00 & 35.53 & 9.60 \\
\hline Gender & Freq. & $\%$ & Freq. & $\%$ & Freq. & $\%$ \\
\hline Male & 651 & 58.4 & 278 & 54.4 & 373 & 61.8 \\
\hline Female & 464 & 41.6 & 233 & 45.6 & 231 & 38.2 \\
\hline Profession/Occupation & Freq. & $\%$ & Freq. & $\%$ & Freq. & $\%$ \\
\hline Federal Civil Servant & 41 & 3.7 & 23 & 4.7 & 18 & 3.1 \\
\hline State Civil Servant & 78 & 7.0 & 41 & 8.4 & 37 & 6.4 \\
\hline LGA Civil Servant & 52 & 4.7 & 26 & 5.3 & 26 & 4.5 \\
\hline Accountant & 36 & 3.2 & 18 & 3.7 & 18 & 3.1 \\
\hline Security personnel & 35 & 3.1 & 7 & 1.4 & 28 & 4.9 \\
\hline Legal Practitioner & 17 & 1.5 & 11 & 2.3 & 6 & 1.0 \\
\hline Lecturer/Teacher & 54 & 4.8 & 29 & 5.9 & 25 & 4.3 \\
\hline Unemployed & 72 & 6.5 & 24 & 4.9 & 48 & 8.3 \\
\hline Student & 114 & 10.2 & 63 & 12.9 & 51 & 8.9 \\
\hline Self employed & 421 & 37.8 & 174 & 35.7 & 247 & 43.0 \\
\hline $\mathrm{NGO/CSO/FBO}$ & 5 & 0.4 & 3 & 0.6 & 2 & 0.3 \\
\hline Media person & 11 & 1.0 & 4 & 0.8 & 7 & 1.2 \\
\hline Clergy & 16 & 1.4 & 8 & 1.6 & 8 & 1.4 \\
\hline Politician & 8 & 0.7 & 5 & 0.1 & 3 & 0.5 \\
\hline Retiree & 30 & 2.7 & 23 & 4.7 & 7 & 1.2 \\
\hline Housewife & 45 & 4.0 & 19 & 3.9 & 26 & 4.5 \\
\hline Other Categories & 28 & 2.5 & 10 & 2.0 & 18 & 3.1 \\
\hline Marital Status & Freq. & $\%$ & Freq. & $\%$ & Freq. & $\%$ \\
\hline Married/Cohabiting & 693 & 62.2 & 334 & 65.9 & 359 & 60.3 \\
\hline
\end{tabular}




\begin{tabular}{|c|c|c|c|c|c|c|}
\hline Separated/divorced & 32 & 2.9 & 17 & 3.4 & 15 & 2.5 \\
\hline Single & 330 & 29.6 & 136 & 26.8 & 194 & 32.6 \\
\hline Widow/Widower & 47 & 4.2 & 20 & 3.9 & 27 & 4.5 \\
\hline Ethnic Background & Freq. & $\%$ & Freq. & $\%$ & Freq. & $\%$ \\
\hline Hausa & 22 & 2.0 & 4 & 0.8 & 18 & 3.0 \\
\hline Ibo & 193 & 17.3 & 91 & 18.0 & 102 & 17.1 \\
\hline Efik/lbibio & 24 & 2.2 & 14 & 2.8 & 10 & 1.7 \\
\hline ljaw & 11 & 1.0 & 6 & 1.2 & 5 & 0.8 \\
\hline Nupe & 12 & I.I & 4 & 0.8 & 8 & 1.3 \\
\hline Benin/Esan & 43 & 3.9 & 30 & 5.9 & 13 & 2.2 \\
\hline Middle Belt & 33 & 3.0 & 8 & 1.6 & 25 & 4.2 \\
\hline Niger Delta & 52 & 4.7 & 20 & 4.0 & 32 & 5.4 \\
\hline Yoruba & 714 & 64.0 & 329 & 65.0 & 385 & 64.4 \\
\hline $\begin{array}{ll}\text { Highest Level of } \\
\text { Education (HLoE) }\end{array}$ & Freq. & $\%$ & Freq. & $\%$ & Freq. & $\%$ \\
\hline No Formal Education & 10 & 0.9 & 3 & 0.6 & 7 & 1.2 \\
\hline Primary Not completed & 25 & 2.2 & 4 & 0.8 & 21 & 3.5 \\
\hline Completed Primary & 28 & 2.5 & 4 & 0.8 & 24 & 4.0 \\
\hline $\begin{array}{ll}\text { Secondary } & \text { Not } \\
\text { Completed } & \end{array}$ & 57 & 5.1 & 18 & 3.6 & 39 & 6.5 \\
\hline Completed Secondary & 204 & 18.3 & 75 & 15.0 & 129 & 21.5 \\
\hline Tertiary not completed & 264 & 23.7 & 136 & 27.1 & 128 & 21.3 \\
\hline Tertiary Completed & 506 & 45.4 & 257 & 51.3 & 249 & 41.5 \\
\hline Other Categories & 7 & 0.6 & 4 & 0.8 & 3 & 0.5 \\
\hline Nature of Area & Freq. & $\%$ & Freq. & $\%$ & Freq. & $\%$ \\
\hline Rural & 202 & 18.1 & 51 & 10.0 & $15 \mid$ & 25.0 \\
\hline Urban & 913 & 81.9 & 460 & 90.0 & 453 & 75.0 \\
\hline Religion & Freq. & $\%$ & Freq. & $\%$ & Freq. & $\%$ \\
\hline Catholic & 160 & 14.7 & 84 & 16.8 & 76 & 12.9 \\
\hline Islam & 273 & 25.1 & 116 & 23.2 & 157 & 26.7 \\
\hline Orthodox Christians & 298 & 27.4 & 133 & 26.5 & 165 & 28.1 \\
\hline Pentecostal & 303 & 27.8 & 154 & 30.7 & 149 & 25.4 \\
\hline Traditional & 37 & 3.4 & 9 & 1.8 & 28 & 4.8 \\
\hline No religion & 17 & 1.6 & 5 & 1.0 & 12 & 2.0 \\
\hline $\begin{array}{l}\text { Economic } \\
\text { Categorisation }\end{array}$ & Freq. & $\%$ & Freq. & $\%$ & Freq. & $\%$ \\
\hline Very Rich & 32 & 3.0 & 30 & 6.0 & 2 & 0.3 \\
\hline Rich & 194 & 17.9 & 135 & 27.2 & 59 & 10.0 \\
\hline Very Poor & 210 & 19.4 & 26 & 5.2 & 184 & 31.3 \\
\hline Poor & 51 & 4.7 & 5 & 1.0 & 46 & 7.8 \\
\hline Average & 597 & 51.1 & 30 & 60.5 & 297 & 50.5 \\
\hline
\end{tabular}

Source: Data from authors' Fieldwork: 2015/2016

(5) As shown in Table I, remittances receiving households (RRHs) are slightly older than the nonremittances receiving households (NRRHs). $\mathrm{RRHs}$ are also slightly older than the average sample age while NRRHs slightly younger than the average sample age. Across all categories, males are more represented than females. The differential sex representation is more for the NRRHs. The predominance of males may not be unconnected with patriarchal nature of the study setting which often makes males' voices more audible and more accessible in household issues. The self-employed are the most represented economic category, followed by the civil servants, the students and the unemployed respectively. Most of the respondents across categories are married/cohabiting, followed by the yet-to-bemarried/Single. The most represented ethnic group is the Yoruba people. This group was followed by the Ibo people and the Niger Delta people. The preponderance of the Yoruba people is sustainable against the background that even though Lagos is a cosmopolitan setting, it is located in the South- 
western part of the country- an area historically and geographically belonging to the Yoruba people.

Most of the respondents across all categories are educated. Very few of the respondents actually either did not have formal education or did not complete primary/elementary school. While a lot of the respondents have tertiary education, a little over half of the RRHs have tertiary education (end of 5).

(6) Clearly reflecting the nature of the research context, most of the respondents $(90.0 \%$ among RRHs, 75.0 among NRRHs and $81.9 \%$ for sample) live in the urban center. It is however important to note that of the two study categories (RRHs and $\mathrm{NRRH}$ s), more of the RRHs live in the urban centers. All common religions in Lagos are represented in the sample list (end of 6).

(7) The least common religious category is the Traditionalists/Atheists. On economic status, more people across categories are average. This was followed by the Very Poor among the NRRHs, and Rich among the RRHs. By the Sample average, this was followed by the Very Poor and then the Rich (end of 7).

Table 2: Common Destinations of International Migrants

\begin{tabular}{|l|l|l|}
\hline Variables & Distributions \\
\hline Destination of Migrants & Freq. & Percentage (\%) \\
\hline United Kingdom & 121 & 23.68 \\
\hline U.S.A. & 171 & 33.46 \\
\hline Dubai & 27 & 5.28 \\
\hline Germany & 27 & 5.28 \\
\hline Italy & 10 & 1.95 \\
\hline Canada & 60 & 11.74 \\
\hline Spain & 20 & 3.91 \\
\hline Australia & 7 & 1.37 \\
\hline South Africa & 20 & 3.91 \\
\hline France & 14 & 2.94 \\
\hline South Korea & --- & --- \\
\hline Malaysia & 13 & 2.54 \\
\hline Saudi Arabia & 3 & 0.58 \\
\hline Holland & 5 & 0.97 \\
\hline Belgium & 12 & 2.34 \\
\hline Other African Countries & 5 & 0.97 \\
\hline Other Non-African Countries & 1 & 0.19 \\
\hline Source Data from author Fieldwork & $2015 / 2016$ & \\
\hline
\end{tabular}

Source: Data from authors' Fieldwork: 2015/2016

Most of the migrants travelled to United States of America, United Kingdom and Canada. These three destinations alone accounted for about 70 percent of migrants' destination countries. These destinations were distantly followed by Malaysia, Dubai and Germany. The findings from the quantitative data were consistently found across all the qualitative sessions (FGDs, IDls and Life Histories). According to discussants at FGD Ibeju Lekki; London (UK) is the most visited place (Discussant 2), some go to London (UK) ... (Discussant 3), it (choice of destination) depends more on what the intention of traveling out is... U.S., U.K... (Discussant 7), U.S.A and U.K... (Discussant 4).

An interviewee during IDI in Alimosho also maintained: UK, US, Canada. Now they go to other places where people are making it (succeeding) but these three places are the traditional places Yoruba people go for a lot of reasons. They have people there, the currency, distance, cost of processing and flight, jobs and so on. In consistency, another interviewee maintained during life history in Alimosho: ...they (migrants) normally like going to United State (U.S)... U.K is like they go to make money legally/illegally and come home but U.S they want to go and settle down and be established.

The finding in Surulere during life history is also consistent with the above:

Ah! First most go to South Africa ${ }^{i x}$ then from there they find their ways to U.K. Some also go to U.S.A. Canada, Britain.

As already indicated by the interviewees and discussants during qualitative sessions, the choice of these three predominant destinations (U.S.A., U.K. and Canada) is not unconnected with the long history of migrations of Nigerians to the places, language (English) and established migration networks that are very critical to successful migration (as predetermined by the migrants and their kinship networks/social networks) (see also Akanle and 
Olutayo, 2012). Other common reasons are; popularly recognized strong economy and currency of the destination countries (see Fonta, et al, 2015 also) among Nigerians. We also tested for the elements (Nature, Volume and Frequency [NVF]) of remittances. This is very important as they have the capacity to provide indications of relationships between remittances and welfare.

Table 3: Elements (NVF) of Remittances in RRHs

\begin{tabular}{|c|c|c|c|c|c|}
\hline \multicolumn{6}{|l|}{ Variables } \\
\hline Nature of Remittances & \multicolumn{3}{|l|}{ Frequency } & \multicolumn{2}{|c|}{ Percentage } \\
\hline Money & \multicolumn{3}{|l|}{425} & \multicolumn{2}{|c|}{83.17} \\
\hline Cloths & \multicolumn{3}{|l|}{232} & \multicolumn{2}{|l|}{45.40} \\
\hline Migration Information & \multicolumn{3}{|l|}{52} & \multicolumn{2}{|l|}{10.17} \\
\hline Computers & \multicolumn{3}{|l|}{67} & \multicolumn{2}{|l|}{13.11} \\
\hline Fashion Accessories & \multicolumn{3}{|l|}{111} & \multicolumn{2}{|c|}{21.72} \\
\hline Channels of Remittances & \multicolumn{3}{|l|}{ Frequency } & \multicolumn{2}{|c|}{ Percentage } \\
\hline Western Union & \multicolumn{3}{|l|}{266} & \multicolumn{2}{|c|}{62.59} \\
\hline Money Gram & \multicolumn{3}{|l|}{122} & \multicolumn{2}{|l|}{28.71} \\
\hline Other Transfer Operators & \multicolumn{3}{|l|}{23} & \multicolumn{2}{|l|}{5.41} \\
\hline Postal Money Order & \multicolumn{3}{|l|}{3} & \multicolumn{2}{|l|}{0.71} \\
\hline Direct to Bank Transfer & \multicolumn{3}{|l|}{41} & 9.64 & \\
\hline Foreign Exchange Bureau & 1 & & & 0.23 & \\
\hline Credit Union & 0 & & & 0 & \\
\hline Travel Agency & 10 & & & 2.35 & \\
\hline Friends/Informal Individuals & 74 & & & 17.41 & \\
\hline Mobile Phones & 1 & & & 1.18 & \\
\hline Brought Back By selves & 21 & & & 4.94 & \\
\hline Internet Transfer & 9 & & & 2.12 & \\
\hline Frequency of Remittances & Frequency & & & Percentag & \\
\hline Weekly & 20 & & & 4.3 & \\
\hline Every two weeks & 13 & & & 2.8 & \\
\hline Monthly & 119 & & & 25.7 & \\
\hline Every two months & 122 & & & 26.2 & \\
\hline Every six months & 98 & & & 21.1 & \\
\hline Yearly & 92 & & & 19.8 & \\
\hline Frequency of Remittances & n The Last $6 \mathrm{~N}$ & nths & & & \\
\hline $\begin{array}{l}\mathrm{He} / \text { She has not sent at all } \\
\text { within the time }\end{array}$ & 36 & & & 7.7 & \\
\hline I-2 times & 224 & & & 47.7 & \\
\hline $3-4$ times & 115 & & & 24.5 & \\
\hline 5-6 times & 52 & & & 11.0 & \\
\hline 7-8 times & 18 & & & 3.8 & \\
\hline $9-10$ times & 21 & & & 4.5 & \\
\hline $1 \mathrm{I}+$ times & 3 & & & 0.6 & \\
\hline Volume of Remittances ${ }^{x}$ & Mean & Std dev & Range & Minimum & Maximum \\
\hline $\begin{array}{lll}\text { Amount Remitted to } \\
\text { Household in the last six } \\
\text { months }\end{array}$ & $\begin{array}{l}\text { N488395.4 } \\
\text { USD\$2466.6 }\end{array}$ & $\begin{array}{l}878745.45 \\
4438.10\end{array}$ & $\begin{array}{l}7989570 \\
40351.3\end{array}$ & $\begin{array}{l}\text { NI0430 } \\
\text { (USD\$52.7) }\end{array}$ & $\begin{array}{l}\text { N8000000 } \\
(\text { USD\$40404.0) }\end{array}$ \\
\hline Respondents' Description c & f Volume of $\mathrm{Re}$ & ittances & & & \\
\hline RsDoVR & & & & & \\
\hline Very much and enough & 126 & & & 25.8 & \\
\hline Much but not enough & 159 & & & 32.6 & \\
\hline Little & 96 & & & 19.7 & \\
\hline Very little & 35 & & & 7.2 & \\
\hline I cannot really describe & 72 & & & 14.8 & \\
\hline
\end{tabular}

Source: Data from authors' Fieldwork: 2015/2016 
The most commonly remitted materials are money, cloths, fashion accessories, computers and migration information respectively. The predominance of money may not be unconnected with its capacity to serve many immediate purposes in households. Also, many migrants send money due to its exchange value in the local markets with relatively weak currency exchange rates. Monies remitted therefore have the capacity to multiply and increase in value especially when exchanged at the local parallel markets (this is known as the black markets in Nigeria). This becomes appreciable against the background that most of the migrants travelled to U.S.A, U.K. and Canada- countries with strong currencies compared to Nigeria (Akanle, 20I2, Akanle, 2009). The three most commonly used channels of remittances are Western Union, MoneyGram and Informal Channels/Friends. This is consistent with earlier findings on nature and channels of remittances (Fonta, et al, 20I5). In other words, since the most commonly remitted item is money, it is therefore sustainable that Western Union and MoneyGram are the most used means of remitting into households. It is however noteworthy that as much as $|7.4|$ percent of the respondents indicated remittances are also sent through friends/informal channels. This may not be unconnected to the high charges commonly levied on remittances to developing countries by the formal channels (Western Union, MoneyGram for example) (Badomo, 20I4, von Burgsdorff, 20I2).

On frequency of remittances, most households receive remittances from overseas in monthsmonthly $(25.7 \%)$, every two months $(26.2 \%)$, six monthly (21.1\%) - and yearly (19.8\%). This shows that there is usually a pattern through which remittances are sent to households. Over half of households receive remittances between I-2 months. Far less proportion of households receives remittances weekly. This variable was further explored over a six months period. Over 80 percent of the households have received remittances from abroad between I- 6 times in the last six months. We investigated volume of remittances financially and it was found that remittances to the households are appreciable. For instance, average monetary remittances to households over the previous six months was N488395.4 (USD\$2466.6). With a further analysis, it was found that average remittances per day (in monetary terms alone) to households is in the region of USD\$13.7. Compared with the newly reclassified poverty threshold as people living on $\$ 1.90$ or less a day, this indicates a capacity for possible positive influence of remittances on household and welfare. The indicated minimum amount of monetary remittances over the previous six months was N10430 (USD\$52.7) while the http://aps.journals.ac.za maximum was N8000000 (USD\$40404.0). Given the importance of this variable, we re-measured it through household self-description of volume of remittances. Almost 60 percent of the remittances receiving households (RRHs) described the remittances they receive as much while only 26.9 percent of the households described the remittances they receive as little while 14.8 percent of households could not readily described size of the remittances they received.

This subject of Elements (NVF) of Remittances in $\mathrm{RRH}$ s was also further examined qualitatively to enhance understanding of the trajectories. According to lyade , a 33 years old business woman during IDI at Iwaya:

It (remittances) is usually money. This is because that is what people can use for many purposes. Most of them (international migrants) send money. Although they also send cars, engines and electronics but it depends on the country you (the migrant) are. I know the lgbo people send materials for business. But for Yoruba people, it is usually money because if they send materials it will tie money down and sometimes they waste. Won a lu opolopo ni gbanjo ni (they will auction most of the materials and it will not be profitable ultimately). Money is the main thing. As about regularity, it depends on how well the person is doing and how much is needed at home. For many people (migrants) it is only when they have (money). But for the people that are doing very well, it is always (frequently) when there is a need. For example, when there are needs to pay school fees, medical issues, rents and chop money (family upkeep).

Another interviewee, Mr. Ayegbogbo, a Civil Servant also added during IDI Alimosho:

It depends on how well that person is doing. That is what will determine what and often (frequency) he/she will send something. Someone that is struggling (not successful) there (at destination) will only send once in a while and the one with regular job and papers (legal documentation/legal immigrant) can say I will be sending you upkeep money every month when I receive salary. So it depends. I think what people send home most is money. For school fees, drugs, rents and parties (social events like funeral/marriage). You know $\circ$ wan be (literally translated as (it is there/or I am also there- this is the local concept for describing social events as common activities) especially among the Yoruba people. Even among the lbos too. They want people to know their own is different because they have somebody for obodo oyinbo (abroad).

Findings during Life Histories were also consistent and instructive. 60 years old Mr. Ugonma, an lbo businessman who spent 10 years in Europe shared his 
personal migration history on the subject matter in Alimosho:

I mostly sent money as upkeep for my parents and siblings. I only sent materials for business. It is regular. Usually anytime they need my attention.

Another 60 years old Mr. Jafar, retiree/selfemployed with 10 years foreign sojourn livelihood also shared his migrations life history on the subject in Lagos Island:

Money is the principal thing (that is sent). They (monies) can easily multiply through exchange rate and it (money) is always ready for use. Also cars and some household things (are sent). Also, (migration) information is key especially when one is planning to bring other people abroad. For most of us (international migrants), it is when we have (can afford something to send). Not many of us can place households on regular pay. Only when there is money and there is need. Especially now that everywhere is tight (in financial and regulation terms) even in Europe and America.

As can be seen in the ethnographic summaries above, there is significant consistency at the intersections of the mix-methods. Just as found in quantitative data above, discussants and interviewees maintained money is the most commonly remitted material. The preponderance of money as the main item/nature of remittances is mostly due to three major reasons. First, money (foreign currency) can appreciate substantially when exchanged in the local currency market especially in the black market/parallel market particularly in Nigeria, like many developing countries, with weak currency compared to major international currencies like the U.S. dollars, Euros and Pounds Sterling. Second, money can easily be immediately spent on the purposes it is meant without delay unlike other materials like motor cars that may never be sold for months or may later be sold at comparatively unprofitable auction price. Third, it is easier for migrants to monitor the uses and used-value of remittances sent through money unlike other materials that may lose value and prone to mismanagement in the process of sale and disposal.

While it was found in quantitative data that there are variations in frequency of remittances, this variation was explained in qualitative data as interviewees/discussants explained the frequency of remittances is usually determined by the combined factors of status of the migrants at destinations, the nature/urgency/necessity of the needs at households (origin) and the socio-economic and regulatory environments at destination. Hence, while those migrants who are documented at destinations and have regular jobs may be able to place households at origin on regular salaries and upkeep allowances, it may not be possible or easy for the undocumented ones who mostly do not work and live on unpredictable income and irregular ways of surviving. Generally, most remittances are tied to needs at households and these needs ultimately determine what is sent, how it is sent, how much is sent and when

it

is sent.

Towards influences of remittances on Welfare (RRHs and NRRHs)

Table 4: Expenditure value of remittance receiving and non-remittance receiving household

\begin{tabular}{|c|c|c|c|}
\hline & $\begin{array}{l}\text { Remittances receiving } \\
\text { Household }\end{array}$ & $\begin{array}{l}\text { Non-remittance } \\
\text { receiving household }\end{array}$ & $\begin{array}{l}\text { t-statistic } \\
\text { (P-value) }\end{array}$ \\
\hline Expenditure on Food & $\mathrm{N} 287922.0(\$ 1454.1)$ & NI60645.3 (\$8II.3) & $6.096(0.000)$ \\
\hline Expenditure on Education & N76 I I 45.4 (\$3844.2) & N338|38.3 (\$ I707.8) & $2.950(0.003)$ \\
\hline Expenditure on Health & $\mathrm{N} 201010.8(\$ 10 \mid 5.2)$ & N64874.7 (\$327.7) & $2.320(0.021)$ \\
\hline Expenditure on Rent & N506333.3 (\$2557.2) & N3I3395.I (\$1582.8) & $1.993(0.047)$ \\
\hline Expenditure on Social Functions & NI38624.3 (\$700.I) & N98I79.I (\$495.8) & $0.47 \mathrm{I}(0.638)$ \\
\hline Expenditure on Vehicles & N279|64.I (\$1409.9) & N74I I $8.3(\$ 374.3)$ & $1.286(0.200)$ \\
\hline $\begin{array}{l}\text { Expenditure on Renovation of } \\
\text { house(s) }\end{array}$ & NI3I563.8 (\$664.4) & N55775.0 (\$281.6) & $1.369(0.175)$ \\
\hline $\begin{array}{l}\text { Expenditure on Building of new } \\
\text { House(s) }\end{array}$ & N36097750.0 (\$1823II.9) & $\begin{array}{l}N 3773400.0 \\
(\$ 19057.6)\end{array}$ & $0.557(0.584)$ \\
\hline Expenditure on Business & N893782.6 (45|4.0) & N928I5.8 (\$468.8) & $0.854(0.395)$ \\
\hline Expenditure on Land Purchase & N54II6I.3 (\$2733.I) & N634600.0 (\$3205.0) & $0.286(0.777)$ \\
\hline Expenditure on Others & N337500.0 (\$I704.5) & $\mathrm{N} 80$ I3.0 (40.5) & $3.933(0.003)$ \\
\hline
\end{tabular}

Source: Data from authors' Fieldwork: 2015/2016

P-value significant at $5 \%$ 
Table 5: Aggregate expenditure value of remittance receiving and non-remittance receiving household

\begin{tabular}{|c|c|c|c|c|}
\hline & $\begin{array}{l}\text { Remittances } \\
\text { Household }\end{array}$ & $\begin{array}{l}\text { Non-remittance receiving } \\
\text { household }\end{array}$ & t-statistic (P-value) & Ratio \\
\hline $\begin{array}{l}\text { Aggregate } \\
\text { Expenditure }\end{array}$ & N6I76|55.3 (\$3||92.7) & N755535.4 (\$38|5.8) & $1.321(0.187)$ & 8.2 \\
\hline
\end{tabular}

Source: Data from authors' Fieldwork: 2015/2016

The immediate two tables above (Table 4 and Table 5) present the analytics of households' expenditure as indicators of relationship of remittances and household welfare. Table 4 presents the difference in expenditure components of households (RRHSs and $\mathrm{NRRHs}$ ) using independent t-test. With the exception of expenditure on land purchase, expenditure components for RRHs are higher (across all expenditures) than the NRRHs. Moreover, expenditure on food, education, health, rent and others (basic indicators of welfare) are significantly higher among the RRHs than among the NRRHs. There is a significant difference in the expenditure components of RRHs and NRRHs. The aggregate expenditure of RRHs is over 8 times higher than that of the NRRHs. This implies that RRHs are more able to meet their welfare needs than the NRRHs as indicated in their expenditure capabilities (see also Akanle and Adesina, 2017).

Table 6: Regression analysis of income, remittances and socioeconomic variables

\begin{tabular}{|c|c|c|c|c|c|c|}
\hline & \multicolumn{2}{|c|}{$\begin{array}{l}\text { Unstandardized } \\
\text { Coefficients }\end{array}$} & \multirow{2}{*}{$\begin{array}{l}\begin{array}{l}\text { Standardized } \\
\text { Coefficients }\end{array} \\
\text { Beta }\end{array}$} & \multirow[t]{2}{*}{$\mathrm{t}$} & \multirow[t]{2}{*}{ P-value } & \multirow[t]{2}{*}{$\begin{array}{l}\text { Influence of } \\
\text { the variables }\end{array}$} \\
\hline & B & Std. Error & & & & \\
\hline (Constant) & 9.620 & .288 & & 33.411 & .000 & \\
\hline Separated/divorced ${ }^{\mathrm{xi}}$ & .190 & .233 & .024 & .814 & .416 & Not sig ${ }^{x i i}$ \\
\hline Single & .319 & .099 & .110 & 3.208 & .001 & Sig \\
\hline Widow & -.122 & .202 & -.020 & -.601 & .548 & Not sig. \\
\hline Civil_servant & .259 & .105 & .078 & 2.466 & .014 & Sig. \\
\hline Accountant & .070 & .188 & .011 & .375 & .708 & Not sig. \\
\hline Security & -.301 & .221 & -.040 & -1.358 & .175 & Not sig. \\
\hline Legal & -.211 & .305 & -.020 & -.692 & .489 & Not sig. \\
\hline Lecturer & .069 & .175 & .012 & .398 & .691 & Not sig. \\
\hline Unemployed & -.153 & .183 & -.025 & -.834 & .404 & Not sig. \\
\hline Student & .060 & .145 & .014 & .414 & .679 & Not sig. \\
\hline Clergy & .074 & .318 & .007 & .232 & .817 & Not sig. \\
\hline Retiree & .516 & .214 & .070 & 2.415 & .016 & Sig. \\
\hline Housewife & 1.095 & .225 & .146 & 4.875 & .000 & Sig. \\
\hline Others & .025 & .179 & .004 & .137 & .891 & Not sig. \\
\hline Rural & -.137 & .097 & -.042 & -1.408 & .160 & Not sig. \\
\hline $\begin{array}{l}\text { Female-headed } \\
\text { households }\end{array}$ & -.421 & .093 & -.144 & -4.539 & .000 & Sig. \\
\hline Flat & -.324 & .105 & -.099 & $-3.07 \mid$ & .002 & Sig. \\
\hline Mini_flat & -.574 & .128 &.$-|4|$ & -4.469 & .000 & Sig. \\
\hline One_room & -1.099 & .174 & -.208 & -6.315 & .000 & Sig. \\
\hline Face me & -.967 &.$|7|$ & -.187 & -5.650 & .000 & Sig. \\
\hline Room_parlour & -.491 & .143 & -.113 & -3.433 & .001 & Sig. \\
\hline Boys quarters & -.980 & .193 & -.165 & $-5.09 \mid$ & .000 & Sig. \\
\hline Duplex & .565 & .157 & .117 & 3.608 & .000 & Sig. \\
\hline Gate_security & .311 & .239 & .039 & 1.300 & .194 & Not sig. \\
\hline $\begin{array}{l}\text { Economic status of } \\
\text { household }\end{array}$ & .483 & .062 & .307 & 7.820 & .000 & Sig. \\
\hline Education & .038 & .031 & .041 & 1.212 & .226 & Not sig. \\
\hline
\end{tabular}




\begin{tabular}{|l|l|l|}
\hline R-square & 0.456 & \\
F-statistics & $20.876(0.000)$ & \\
\hline
\end{tabular}

Source: Data from authors' Fieldwork: 2015/2016

P-value significant at $5 \%$ level.

Table 6 presents the regression results to determine the influence of remittances and some socioeconomic variables on households' income. As shown in the last panel of the table, the model fit is admissible with an R-square 0.456 and joint contribution of the included independent variables in the model are equally significant $(F<0.05)$. In term of individual significance, it is found that gender of household head, occupation, model of dwelling place and economic status are significant predictors of household income.
While receiving remittances in households tends to increase household income (for instance $B$ is positive), by significance of influence, receiving remittances may not outrightly/sufficiently explain household income. We then turn to expenditure as expenditure have been found in the literature to be a better measure of influence of remittances/financial interventions on household welfare (see Alemu, et al, 2016, Fonta, et al, 2015, Nwaru, lheke and Onyenweaku, 20II).

Table 7: Regression Analysis of expenditure, remittances and socioeconomic variables

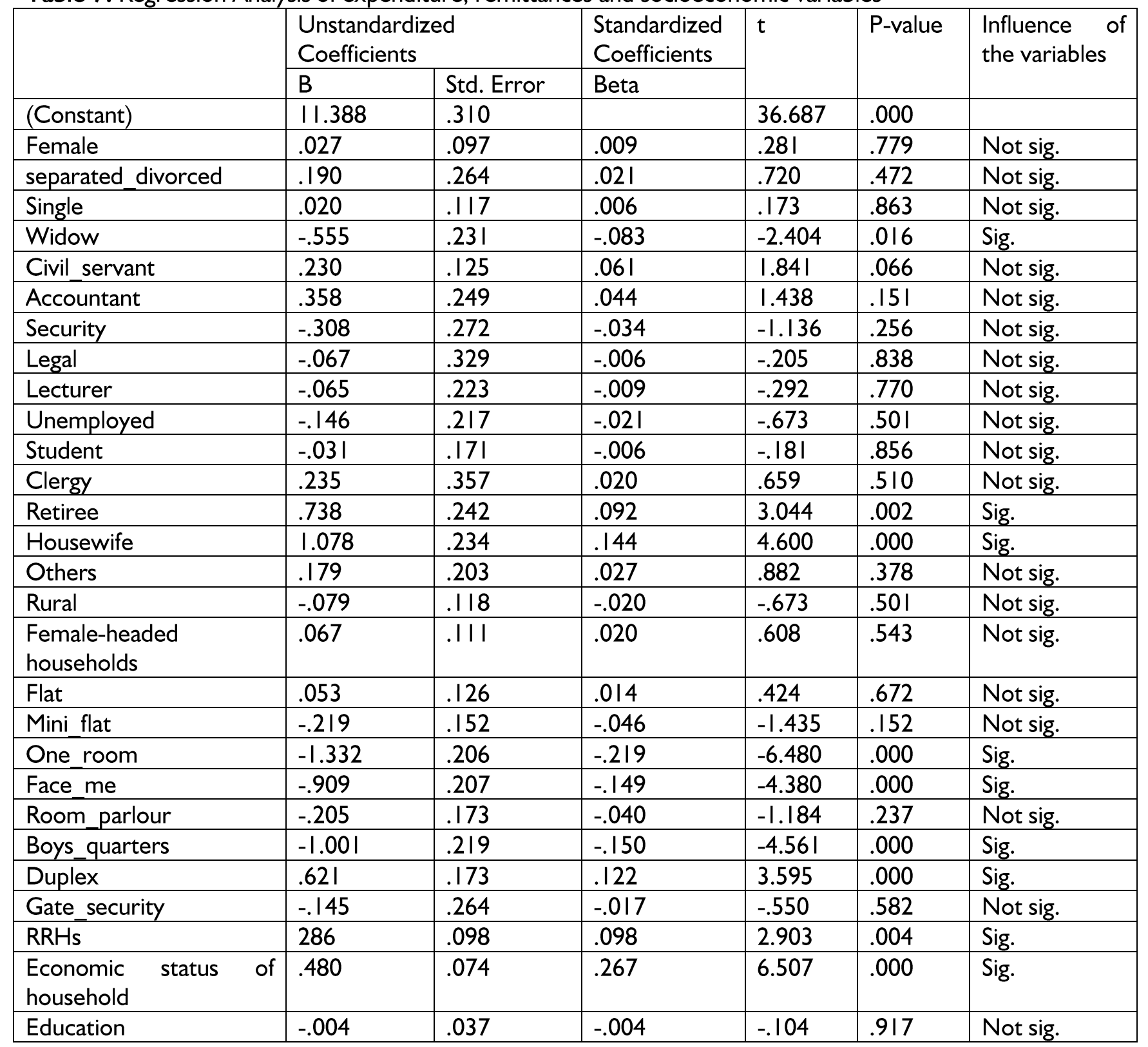




\begin{tabular}{l|l}
\hline R-square & 0.414 \\
F-statistics & $17.850(0.000)$ \\
\hline
\end{tabular}

Source: Data from authors' Fieldwork: 2015/2016

P-value significant at $5 \%$ level.

Findings on remittances and expenditure are definitive as presented in Table 7 . Hence, it is noteworthy that receiving remittances in households increases households' capabilities to increase expenditure and meet welfare needs. By significance of influence, receiving remittances explains household expenditure and impacts welfare substantially. Moreover, significant variables include; marital status, occupation, model of dwelling place, remittances and economic status of the household. It is found that RRHs particularly have better capacity to increase their expenditures on welfare enhancing items/products and services (for example food, health, education, rent, houses, businesses and so on) by $28.6 \%$ compared to the NRRHs. The findings from quantitative data were later further explored through qualitative data. This yielded more insights into the positive relationships between remittances and welfare in the quantitative data. Across all qualitative methods, most of the interviewees/discussants maintained remittances positively affect households' welfare. According to Mr. Ifeanyichukwu, 28 years old Youth Corper/businessman from Enugu, during IDI in Ikorodu:

Once you travel (emigrate), you can work and send things home. You can send money, cars, cloths, electronics, information and so on. All these things can be converted to personal use and they can be sold. In whichever way, they affect the families positively compared to those without anyone abroad. For example, in my place (ethnic group [he is lbo]), when one travels out (emigrate) and come back first is to build house for the family and buy a car for them to make them comfortable then at interval send them money. (On if these remittances affect households' welfare). You can see this (improvement in welfare) from the new quality of life they (households) now live especially where they live, how they move around, the respect they now command (in the community) and so on. They (the families) get recognition from the community because they have somebody abroad.

Another interviewee, Mr. Obayemi ljaoye also maintained the positive relationships of remittances and household welfare by citing a real case during IDI at lkeja:

A friend told his brother abroad that he (the brother abroad) doesn't want to help him. His brother then inquired what assistance he needed. He told his brother he needed a Commuter Bus (a very http://aps.journals.ac.za popular bus usually used for commercial transportation in Nigeria) to aid (assist) him better himself. One way or the other it (the bus) was sent over (to Nigeria). Today, from that one Committer Bus, $\mathrm{He}$ (the brother in Nigeria) owns a house and some other busses. All I'm saying is no matter what is sent, so long the receiver knows what he/she is doing (is serious) and is not a waster, he should make something (success) out of it.

A migrant of 56 years of age, Pacollo Orge, shared his personal experience during life history in Ibeju Lekki:

I was sending it (money home) because the finance of this place (Nigeria) wasn't okay. At times I send cash. I was paid in dollars (abroad). My siblings were able to go to school, they were going to their lessons. They were doing good. Even when I called I heard they put doors in our house in the village even they plastered it.

Another migrant, Miss Ayelamashe, 40 years old who lived in the U.K., U.S.A. for at least a decade also agreed with the positive relationships between remittances and household welfare during Life History at Surulere:

It (emigration/remittances) will affect it (family/household welfare) positively, naturally the way this country is going you can see this country doesn't have anything to offer so I am not against travelling abroad for greener pastures. At least I have travelled and I know some families who sent the children there (abroad) and the children are sending money back and it has changed the status of the family. I sent things to my family when abroad and it made a lot of difference in terms of welfare. We could afford basic needs and do some extra. If you are there and you are making something, you have got to share with home. That is natural. They (people at origin) will not even allow you rest and conscience will not allow you too. This is Africa. We care about our families. It does not matter where you are abroad and how westernised you are, the African in you will crave to support home. Even your friends abroad will use it to abuse you if you do not send things home. They will always remind you that ile la bo si mi oko (literally translated you will return home after going to the farm).

From the ethnographic summaries above, a significant consistency can be observed in the data/analysis. Positive relationships exist between remittances and household welfare especially when remittances are put to constructive use on products 3206 
and services that have direct bearing with welfare. Another major finding that is noteworthy in the qualitative data is the non-material/social welfare impact of remittances and having a kin abroad. Aside the material gains of remittances, enhanced social status, prestige and respect are accorded families/households with people abroad particularly when the families/households receive remittances. As the tangible/physical remittances directly impact household welfare, they also directly or indirectly impact social status and prestige of the households in the community which is very definitively important as indicator of welfare.

\section{Discussions}

Common perspectives on remittances, poverty alleviation and welfare at the level of household are that migrants remit for risk distribution and livelihood and/or a combination of the two (World Migration Report, 2013, de Haas, 2007, Chukwuone, et al, 2012). The premise of these perspectives is that migrants' remittances do not operate in vacuum but within deep-seated socioeconomic and historical spaces that expect migrants to support households either for pure charity, as a social obligation or to reduce risk of livelihood deprivation. Migrants' remittances thus become not only beneficial at individual, households and community level but also at national level to the extent that such remittances become important components of finance as both investments drivers and consumption sustainers (The World Bank, 20I5, Gabriel, 20I5). While remittances from migrants can alleviate poverty and increase welfare (Chukwuone, et al, 20/2), they can also build the culture of dependency (migration pessimism) (de Hass, 2007). This is, for instance, where members of households who have never migrated become too dependent on remittances to meet households' needs. This kind of orientation consequently build perpetual inequality and patron-client relationships at households rather than encouraging innovative and sustainable survival approaches out of poverty (see World Migration Report, 2013, Chukwuone, et al, 2012). Remittances are myriad in types (they can be financial and non-financial [Akanle and Olutayo, 2009]) and they do not necessarily eradicate poverty and increase welfare (Togunde and Osagie, 2009, Gupta, Hernandez-Coss and Bun, 2006).

These constellating theoretical positions fall broadly within the theoretical duo of Migration Optimists and Migration Pessimists (de Haas, 2007) debates. These theoretical debates largely center on the intentionalities and impact of remittances as key actors (migrants and kin at households) interact across spaces and time as determined by needs and orientations. For the migration optimists, remittances flow would help households alleviate poverty, increase welfare and jumpstart development. For the migration pessimists, remittances build culture of overdependence, negate productivity and withdraw human capital from traditional and developing countries. The New Economics of Labour Migration (NELM) however have more definitive impacts on contemporary migration and remittances studies (Fonta et al, 2015). For the NELM (Lucas and Stark, 1985, Stark and Bloom, 1985) migration and remittances are instrumentalities of spreading households' survival risks in the face of underdevelopment and poverty at origins regardless of the immediate motives of migration and remittances whether for purely altruistic purposes, self-seeking/self-interested/selfish purposes or intent to return orientation.

Ultimately, remittances and migration become shock absorbing instruments for households who devise strategies through migration to cope in socioeconomically challenging systems of many developing countries. Findings from this study largely uphold the theoretical views of migration optimists and NELM. As found in the data above, remittances have significant impacts on welfare enhancing expenditures of households as they were more able to meet their survival and investment needs through school fees, rent, houses, commercial activities- like transportation-, medical bills and even improvement of households social status. In line with arguments of NELM, migrants studied remitted for the three major reasons. The migrants remitted to households for a combination of purely altruistic reasons (to meet households needs of food and health care for instance), self-interested reasons (when migrants instructed kin to build house(s) for them) and for return reasons (when migrants send monies for proxy investments and property) since they may wish to return at a time- ile la bo si mi oko (literally translated you will return home after going to the farm) as succinctly put ethnographically by one of the migrants interviewed. It is important to note that the purely altruistic, self-seeking and intention to return constructs of remittances are not mutually exclusive but largely overlapping. It is not therefore very appropriate to drive a theoretical wedge across the reasons for remitting. For example, a migrant may remit at a time or overtime for reasons that combine the three constructs. When a migrant remits to build house for him, pay school fees, increase family social status in community or even celebrate social events, every one of these reasons may combine altruism, self-seeking and intention to return at the same time. 


\section{Conclusion}

Based on findings from the study that informed this article as presented above, it is possible to conclude that remittances from international migrants to households in Nigeria, like in many other developing countries, are much, substantial and appreciable. While different things are remitted, money is the most remitted material given its many advantages as already demonstrated above. Unlike many previous studies and migration pessimists who maintained remittances are mostly used for unproductive consumptions, we found that remittances to households are used for many other purposes than unproductive consumptions. In fact, significantly larger proportion of remittances to the households studied are used for directly productive purposes like establishing businesses, building houses, education (payment of school fees) and others. Even others like feeding and health care and social functions have their productive implications in the short and long run. Remittances to households in Nigeria have positive influences on welfare of remittances receiving households. It is thus high time governments and other stakeholders began to innovate policies and strategies to better leverage on remittances as development and poverty alleviation financing instruments. There is a need for the Nigerian government, and many other developing countries', to effectively partner its diaspora to better channel remittances home. As at now, Nigerians largely subsist abroad without government oversight. Nigerian government must pay closer attention to the existences of Nigerians abroad and protect their interests abroad diplomatically to safeguard their remittances inflow and interest of the country. Unfortunately, many developing countries, including Nigeria, lack actively workable policy frameworks for partnering and protecting the diaspora. Where such frameworks exist, they are mere policy papers without effective implementation. The need to leverage on remittances is especially important now that other investment financing mechanisms are dwindling and global prices of oil (the main source of foreign exchange to Nigeria) are nose-diving. From the findings of this article, remittances are major welfare life-lines for many households in Nigeria as the nation face tough economic situations and the government, other stakeholders, development partners and key actors must pay more attention to the roles of remittances in household welfare.

\section{Acknowledgements}

We acknowledge that the study which informed this article was fully funded by the South African Research Chair (SARChl) in Social Policy, University of South Africa (UNISA), South Africa. The South African http://aps.journals.ac.za
National Research Foundation and the University of South Africa supported Dr. Akanle's work. We appreciate the editor and the editorial team of APS for their professionalism in facilitating publication of this article. Very useful comments, queries and suggestions of APS peer reviewers on earlier drafts of this article are also expressly acknowledged. We thank our respondents, discussants and interviewees who gave their time, spaces and knowledge during the fieldwork.

\section{References}

Adesina, J. O. 2002/2006. Development and the challenge of Poverty: NEPAD, post-Washington Consensus and Beyond. In J. Adesina, Y. Graham \& A. Olukoshi (eds). Africa and Development Challenge of the New Millennium. London: ZED Books.

Akanle, O. and Adesina, J.O.. 2017. International Migrants' Remittances and Kinship Networks in Nigeria: The Flip-Side Consequences. Journal of Anthropological Research. DOI: 10.1086/690609 http://www.journals.uchicago.edu/doi/abs/I0.1086 1690609.

Akanle, O., Abebe Ejigu Alemu and Jimi. O. Adesina. 2016. The existentialities of Ethiopian and Nigerian migrants in South Africa. International Journal of African Renaissance Studies - Multi-, Inter- and Transdisciplinarity. II.2, I39-158.

Akanle, O. and Olutayo, A.O. 2012. Ethnography of Kinship Constructions among International Returnees in Nigeria: Proverbs as the Horses of Words. Journal of Anthropological Research. 68.2, 249-272.

Akanle, O. 2013. The Development Exceptionality of Nigeria: The Context of Political and Social Currents. Africa Today, 59.3, 31 -48.

Akanle, O. 201I. Kinship Socio-Economics of Nigerian International Migrants. Diaspora Studies, 4. 2, $105-124$.

Akanle, O. 2012. Kinship Support Orientations and Class Dynamics of Nigerian International Migrants. International Review of Modern Sociology, 38.I, |3|-|53.

Akanle, O. and Adesina, J.O. 20I5. Corruption and the Nigerian Development Quagmire: Popular Narratives and Current Interrogations. Journal of Developing Societies 31, 42I-446.

Akanle, O. and Olutayo, O.A. 20II. Kinship construction variability among Nigerian international migrants: The context of contemporary Diaspora. Human Affairs 21. 4, 470-480.

Akanle, O. and Olutayo, A.O. 2009. Emancipating Remittance Discourse: A Look at Extra-financial remittance in Nigeria. Global Development 
Studies: International Development Options. 5, 34, $189-212$.

Alemu, A.E., Maertens, M., Deckers, J., Bauer, H. and Mathijs, E. 2016. Impact of supply chain coordination on honey farmers' income in Northern Ethiopia. Agricultural and Food Economics. 4.9, I-2I.

Alkire, S, Foster, J, Seth, S, Santos, M.E. Roche, J.M. and Ballon, P. 2015. Multidimensional poverty measurement and analysis. Oxford: University Press, UK.

Alkire, S. and Santos, M.E. 2010.Acute Multidimensional Poverty: A New Index for Developing Countries. OPHI Working Papers 38. University of Oxford.

Andersson, L. 2014. Migration, remittances and household welfare in Ethiopia. UNU-MERIT Working Papers, 014-004.

Anyanwu, J.C. 20II. International Remittances and Income Inequality in Africa.Working Paper Series. No. 135. African Development Bank Group.

Anyanwu, J.C. 20 I2. Accounting for Poverty in Africa: Illustration with Survey Data from Nigeria. Africa Development Bank Group Working Paper Series. No. I49-May. Tunis: African Development Bank.

Arifeen, A. 2013. Understanding the contribution of remittances at the macroeconomic and household levels and exploring how these transfers could be better leveraged for development in Bangladesh. Background paper prepared for a consultative workshop titled 'Mainstreaming Migration into National Development: Developing a Roadmap for Bangladesh Vision Formulation Workshop', Dhaka, 4-5 September.

Balde, Y. 2009. Migrants' Remittances and economic growth in Sub-Saharan Africa. http://www.umdcipe.org/conferences/Maastricht/ conf_papers/Papers/Remittances_and_Growth_in SSA.pdf. Accessed on 13 April 2016.

Bodomo, A. 2014. Why remittances work better than aid. This is Africa: A Global Perspective. http://www.thisisafricaonline.com/Analysis/Whyremittances-work-better-than-aid. Accessed on I3 April 2016.

Chandy, L Ledlie, $\mathrm{N}$ and Penciakova, V. 2013. Africa's Challenge to End Extreme Poverty by 2030: Too Slow or Too Far Behind? http://www.brookings.edu/blogs/upfront/posts/2013/05/29-africa-challenge-endextreme-poverty-2030-chandy. Accessed on 13 April 2016.

Chukwuone, N. Amaechina, E., Enebeli-Uzor, S.E, lyoko, E. and Okpukpara, B. 2012. Analysis oflnfluence of Remittance in Nigeria.Partnership for Economic Policy (PEP) Working Paper 201209. de Haas, H. 2007. Remittances, Migration and Social Development: A Conceptual review of the literature. Social Policy and Development Programme Paper. 34. Geneva: UNRISD.

Devarajan, S. 2008. Poverty in Africa and elsewhere. In Africa can end poverty. World Bank: http://blogs.worldbank.org/africacan/poverty-inafrica-and-elsewhere. Accessed 30/06/2015. 10:43AM.

Dieye, A.M. 2015. Head of UNDP on remittances as a tool for financing development. New York: UNDP.

Dzingirai, V., Mutopo, P. and Landau, L.B. 2014.Kinship, Social Networks and Remittances from South Africa to Zimbabwe. Working Paper 18. UK's Department for International Development (DFID).The UK Department for International Development (DFID).

Fonta, W.M. Ayuk, E.T. Chukwu, J.O. Onyukwu, O.E. and Agu, C.C. 2015. Dynamics of remittance utilization by Nigerian households. Progress in Development Studies. 15, 4. 343-357.

Gabriel, O. 2015. Nigerian Living Abroad Remitted $\$ 2 \mathrm{Ibn}$ in 20I4- World Bank. http://www.vanguardngr.com/20I5/04/nigeriansliving-abroad-remitted-2 I bn-in-2014-world-bank/. Accessed 26/06/20I5. 14:30PM.

lheke, O. 20I0. Impact of migrant remittances on efficiency and welfare of rural smallholder arable crop households in south eastern Nigeria. Ph.D Dissertation Michael Okpara university of Agriculture, Umudike, Nigeria.

Jimenez, E.V. and Brown, R.P.C. 20I2. How responsive are remittances to recipients' welfare? Evidence from Figi. International Migration. 5I, I80-20I.

Kiiru, J.M. 2010. Remittances and Poverty in Kenya. Paper submitted to be considered for the poster session "New faces for African Development" Dakar, Senegal, 27-30 June.

Lu, Y. 20I2. Household Migration, Remittances and Their Impact on Health in Indonesia. International Migration. 15, 202-215.

Lucas, R.E.B. and Stark, O. 1985. Motivations to Remit: Evidence from Botswana. Journal of Political Economy 93, 90I-I8.

Mishi, S. and Mudziwapasi, L. 2014. Remittances and sustainability of family livelihoods in Zimbabwe: Case Study of Chegutu Town. ERSA Working Paper 440. Pretoria: South Africa.

Nwajiuba, C. 2005. International Migration and Livelihoods in Southeastern Nigeria.Global Migration Perspectives. No. 50. Global Commission on International Migration. Switzerland. 
Nwaru, J.C., Iheke, O.P. and Onyeweaku, C.E. 20II. Impact of Migrant Remittances on the Welfare of Arable Farm Households in South Eastern Nigeria. Human Ecology Review. 18, 2. 159-166.

Odozi, J.C, Awoyemi, T.T and Omonona, B.T. 2010. Household poverty and inequality: the implication of migrants' remittances in Nigeria. Journal of Economic Policy Reform. 13.2.

Pp. 191-199.

Olowa, O.W, Awoyemi, T.T. Shittu, M.A and Olowa, O.A. 2013. Effects of Remittances on Poverty among Rural Households in Nigeria. European Journal of Sustainable Development, 2.4, 22395938.

Olowa, O.W. and Awoyemi, T.T. 20I4.Determinants of migration and remittances in rural Nigeria.American Journal of Agricultural Research I.2, 20-26.

Quartey, P. 2006. The impact of migrant remittances on household welfare in Ghana. Nairobi: African Economic Research Consortium.

Stark, O. and Bloom, D.E. 1985. The new economics of labor migration. American Economic Review 75, I73-78.

The MDG Report 2014. Assessing Progress in Africa Towards the Millennium Development Goals. New York: United Nations Development Programme (UNDP).

The World Bank. 200I. World Development Report 2000/200 I: Attacking Poverty. Washington DC: The World Bank.
The World Bank. 2013. Press Release: Annual Report: End extreme poverty 2030 Promote shared prosperity. Washington DC: The World Bank.http://www.worldbank.org/en/news/pressrelease/20I5/04/I3/remittances-growth-to-slowsharply-in-2015-as-europe-and-russia-stay-weakpick-up-expected-next-year.

Accessed 26/06/20I5. 14:27PM.

The World Bank. 2015. Remittances growth to slow sharply in 2015, as Europe and Russia stay weak; pick up expected next year. Washington DC: The World Bank.

The World Bank/International Monetary Fund (IMF). 2016. Development Goals in an Era of Demographic Change: Global Monitoring Report 2015/2016. Washington: The World Bank/IMF.

Togunde, D.R. and Osagie, S.O. 2009. Icons of progress: returnees' effects on decisions by Nigerians to migrate to the U.S. International Journal of Modern Sociology, 35. I, I I 5- I 35.

Uduku, O. 2002. The Socio-economic basis of a diaspora community: lgbo buike. Review of African Political Economy, 92, 30I-31 I.

von Burgsdorff, D. 2012. Strangling the Lifeline: An analysis of remittance flows from South Africa to Zimbabwe. Passport Report. I-I3.

World Migration Report. 2013. Geneva: International Organisation for Migration.

\footnotetext{
${ }^{i}$ Household welfare as used in this article refers to variable standard of living of a group of people occupying/sharing common household existences and identities. Different variable indicators are used in this article to systematically measure household welfare to document welfare contours as moderated by remittances from international migrants.

iSometimes we considered welfare and poverty synonyms in this article because most people, who are not scholars/or academics, often understand welfare (or even wellbeing) as demonstrative elemental dynamic of poverty. So, when we sometimes refer to welfare, we allude to outcomes of demonstrative dynamics of poverty whether in terms of positive or negative variation in wellbeing or constancy. We used the concept and variable welfare in this article in the order of Iheke (2010) and Quartey, 2006) as economic wellbeing of an individual, group, or economy as conceptualized by utility functions of intervention(s) depending on how individuals, groups, nations and societies fair. Generally, welfare represents people's standard of living and household income and consumption
}

expenditures on food, education and health for example are used as proxies for welfare indicator.

iii Data they give

iv No negative connotation is intended in the use of this concept. It was adopted in this article because of its analytical and descriptive suitability.

$\checkmark$ These three angles of remittances are referred to as elements of remittances in this article.

${ }^{v i}$ See Akanle, O. and Adesina, J.O. 2015. Corruption and the Nigerian Development Quagmire: Popular Narratives and Current Interrogations. Journal of Developing Societies. 31.4. Pp. 421-446.

vii This can be through hiring of consultants and experts from ODAs'/aids' giving nations or through purchasing of equipment from the ODAs'/aids' giving nations for example.

viii The youngest respondent is 18 years old while the oldest respondent is 94 years old. Median age is 35 years and the range of respondents' age is 76 .

${ }^{i x}$ South Africa is usually a transit point in the migration course of the migrants. South Africa is normally not a final destination for many. 
$x$ We first measured the volume of remittances to households through amount of money remitted. This approach was adopted for two major reasons. First, vast majority of our respondents (over 80\%) indicated that money is the most sent remittance. Second, money is the most objective and the most amenable indicator of volume of remittances (see also Fonta et al, (2015), Jimenez and Brown (2012), Lu (2012), Nwaru, Iheke and Onyenweaku (2011).

xi Dummy variable development: In dummy variable creation, it is essential to identify the response and the base categories. The response category is included in the model.

\footnotetext{
${ }^{\text {xii }}$ Not Significant

xiii Significant
} 